\title{
Успішний випадок використання радикальних операцій на пізніх стадіях раку товстої кишки
}

У статті представлено зібрані, оброблені і проаналізовані результати лікування 31 хворого зі злоякісними пухлинами товстої кишки на пізніх стадіях, ускладненими гострою кишковою непрохідністю та перфорацією кишки, перитонітом за 2018 рік. Було визначено співвідношення оперативних втручань залежно від локалізації пухлини та анатомічних особливостей. Для ілюстрації матеріалу представили особистий клінічний випадок використання радикальних операцій на пізніх стадіях раку товстої кишки.

Ключові слова: злоякісні пухлини товстої кишки; радикальні операції; кишечна непрохідність.

Онкологічні захворювання є однією з найактуальніших проблем громадського здоров'я в Україні, зокрема в м. Дніпро. Близько 30-35 \% випадків раку товстої кишки, ускладненого кишковою непрохідністю, призводять до виконання розширених та комбінованих хірургічних втручань в ургентному порядку.

Мета роботи: дослідити та проаналізувати ефективність лікування пацієнтів з пухлинами товстої кишки залежно від методу оперативного лікування, а також більш докладно розглянути клінічний випадок.

Дослідження проводили на базі К3 “Дніпровське КОШМД” ДМР”. Для цього обрано було 31 пацієнта зі злоякісними пухлинами товстої кишки, ускладненими гострою кишковою непрохідністю. Чоловіки - 21 (67,7 \%), жінки - 10 (33,3 \%). Середній вік складав 66,8 року.

Встановлено, що експозиція (в днях) залежить від локалізації пухлини. Пацієнти були госпіталізовані, в основному, в перші 4 доби від початку захворювання, пухлина локалізувалась у висхідній частині ободової кишки та прямій кишці, 13 діб - при локалізації пухлини в сліпій кишці.

Щодо оперативних втручань, частіше виконувались паліативні операції, але мали місце радикальні операції, а також симптоматичні, але останні супроводжувались більшою післяопераційною летальністю. Правостороння геміколектомія виконувалась в 100 \% при локалізації пухлини в сліпій та висхідному відділі ободової кишки. При пухлинах із локалізацією в прямій кишці - передня резекція, обструктивна резекція та двоствольна сигмостомія по 33,3 \% відповідно. При локалізації пухлин в селезінковому куті - лівостороння геміколектомія в 66,7 \% та прошивання перфорації пухлини (33,3 \%). При розташуванні пухлини в ректосигмоїдному відділі виконували двоствольну сигмостомію (33,3 \%), обструктивну резекцію (22,2 \%) та класичну операцію Гартмана (11,1 \%). Також останню виконували при локалізації пухлини в сигмоподібній кишці майже в 10 \% випадків. Рідше використовували оперативні втручання в об'ємі трансверзостомії, ілеотрансверзостомії, санації та дренування черевної порожнини.

Перевагою операції Гартмана $є$ резекція пухлини на першому етапі та одночасна ліквідація непрохідності. Ця операція достатньо радикальна в онкологічному плані, тим більше після неї залишається можливість відновлення безперервності товстої кишки. При перфорації раку ободової кишки необхідно вирішити дві задачі - боротьба з перитонітом та лікування злоякісного новоутворення. Враховуючи високу частоту летальності після симптоматичних і радикальних операцій (відповідно по $33,3 \%)$, то операцією вибору в третини хворих $є$ виведення колостоми з наступним можливим виконанням другим етапом операції Гартмана.

Незважаючи на удосконалення діагностики пухлин товстої кишки, в більшості випадків раку сліпої кишки, а також лівої половини ободової кишки, діагноз встановлюється на пізніх етапах, при наявності ускладнень, провідне місце серед яких посідає гостра обтураційна кишкова непрохідність. Літній вік хворих, наявність у них супутніх захворювань, пізня госпіталізація від моменту розвитку кишкової непрохідності $є$ основними причинами незадовільних результатів лікування даної категорії хворих.

Пропонуємо до уваги клінічний випадок, який стосується пізньої стадії пухлини, яка пенетрувала у всі шари передньої черевної стінки.

Пацієнт А., 68 років, госпіталізований 01.07.2019 р. зі скаргами на наявність в лівій боко- 
вій ділянці черевної стінки колостоми та періодичний біль у правій половині живота, періодичне підвищення температури тіла до $37,5{ }^{\circ} \mathrm{C}$, утруднене відходження калу та газів за стомою. Останні турбують протягом 2 місяців. Із анамнезу - 19.05.2011 оперований з приводу раку ректосигмоїдного відділу товстої кишки, pT4 N0M0, ст. IIB, ускладнена перфорацією пухлини та каловим перитонітом 3 накладанням сигмостоми та асцендостоми. Останню було накладено у зв' язку з діастатичним розривом стінки висхідного відділу ободової кишки, яка в подальшому самостійно закрилася.

На момент госпіталізації стан хворого середнього ступеня тяжкості. Астенічного типу, зниженого харчування. Шкіра та слизові чисті, блідорожеві. Живіт помірно здутий, бере участь в акті дихання. Візуалізується післяопераційний рубець (п/о) після серединної лапаротомії. В лівому боковому відділі - п/о рубець після асцендостомії. Пальпаторно - живіт м'який, помірно болючий у правому боковому відділі, де пальпується щільне пухлиноподібне утворення, розміром 10х6 см, обмежено рухоме. В лівому боковому відділі функціонуюча сигмостома; гази і кал відходять; утвір сигмостоми рубцево звужений (рис. 1).

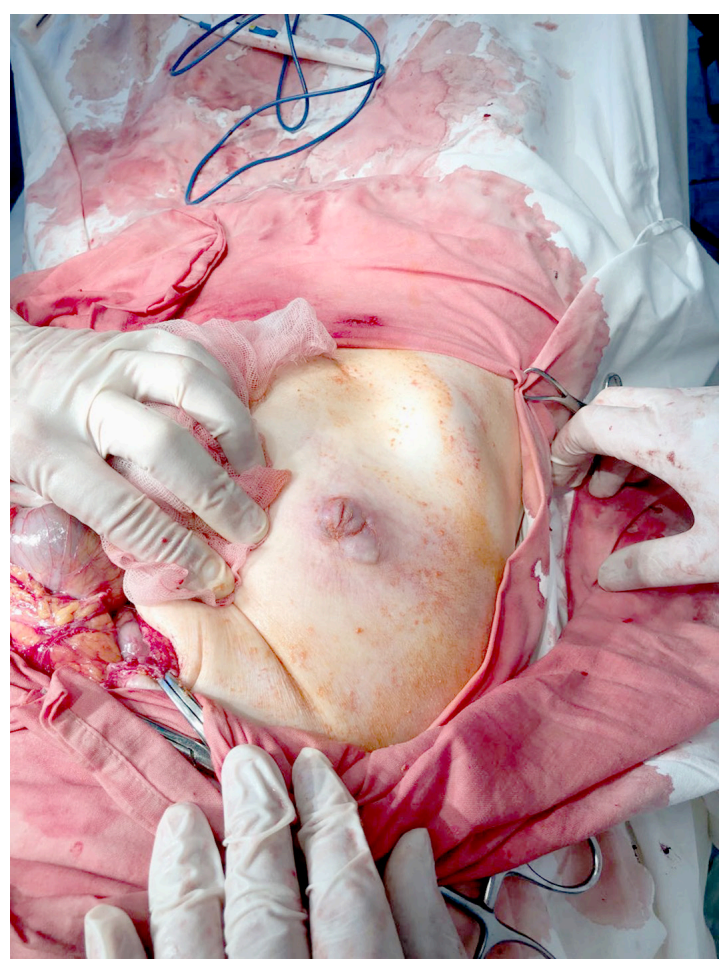

Рис. 1. Зовнішній вигляд хворого безпосередньо перед операцією.
03.07.19 виконано радикальне оперативне втручання в об'ємі правостороння геміколектомія. Під час операції - поширений спайковий процес із формуванням рубцевих зрощень між кишечником, черевною стінкою, фрагментами великого сальника. Сліпа кишка і висхідний відділ кишки роздуті до 6-7 см. У висхідному відділі ободової кишки визначається щільна пухлина 10x8x8 см, малорухома за рахунок проростання в передню-бокову черевну стінку, яка обтурує просвіт кишки. Іншої патології в черевній порожнині немає (рис. 2).

Із патологогістологічного дослідження: помірнодиференційована аденокарцинома з проростанням всіх шарів стінки кишки.

Післяопераційний період - без ускладнень. Післяопераційна рана загоїлась первинним натягом. Хворий виписаний на 16 добу для спостереження лікаря-онколога за місцем проживання 3 відповідними рекомендаціями.

Даний клінічний випадок зайвий раз підтверджує можливість використання радикальних операцій у випадках пізньої стадії раку товстої кишки та тяжких ускладнень, пов'язаних з обтурацією та стриктурою просвіту кишки.

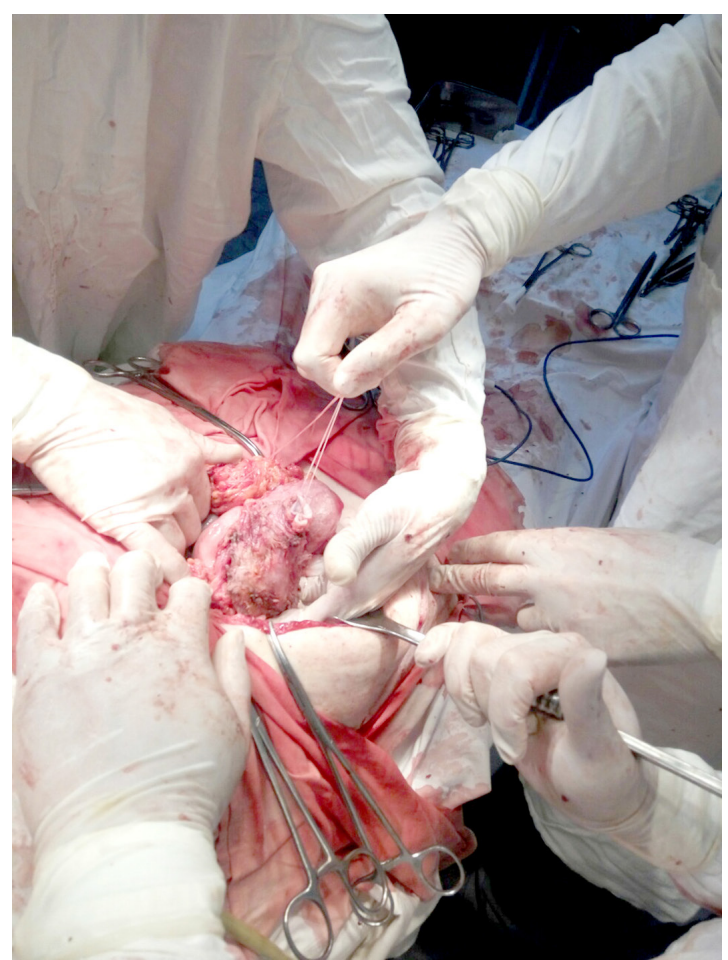

Рис. 2. Основні етапи виділення пухлини в комплексі з оточуючими тканинами. Це потребувало прецизійної оперативної техніки з застосуванням електрозварювального апарата Патона. 


\section{СПИСОК ЛІТЕРАТУРИ}

1. Практическое руководство Всемирного гастроэнтерологического общества (WGO Practice Guidelines) и Международного союза по профилактике рака пищеварительной системы: скрининг колоректального рака / S. Winawer, M. Classen, R. Lambert [et al.]. - World Gastroenterology Organisation, 2008. -17 c.

2. Захараш М. П. Проблемы скрининга колоректального рака в Украине / М. П. Захараш // Здоровье Украины. - 2011. № 6. - С. 22-23.

\section{REFERENCES}

1. Winawer, S., Classen, M., Lambert, R., Fried, M., Dite, P., Goh, K.L., ..., \& Krabshuis, J. (2008). Prakticheskoe rukovodstvo Vsemirnogo gastroenterologicheskogo obshchestva (WGO Practice Guidelines) i Mezhdunarodnogo soyuza po profilaktike raka pishchevaritelnoy sistemy: Skrining kolorektalnogo raka [World Gastroenterological Society (GGO) Practical Guide for the International Union for the Prevention of Digestive Cancer: Screening for Colorectal Cancer]. World Gastroenterology Organisation [in Russian].

2. Zakharash, M.P. (2011). Problemy skrininga kolorektalnogo raka $\mathrm{v}$ Ukraine [Problems of screening for colorectal cancer in Ukraine]. Zdorovye Ukrainy - Health of Ukraine, 6, 22-23 [in Russian].
3. Циммерман Я. С. Колоректальный рак: современное состояние проблемы / Я. С. Циммерман // Вест-ник хирургической гастроэнтерологии. - 2012. - Т. 2. - С. 50-59.

4. Abdominal surgical emergencies in patients with advanced cancer / F. Dumont, D. Goere, C. Honore, D. Elias // J. Vasc. Surg. - 2015. - Vol. 152 (Suppl. 6). - P. 91-96.

5. Багненко С. Ф. Неотложная онкология - пути решения проблемы / С. Ф. Багненко, А. М. Беляев, А. А. Захаренко // Вестник хирургии им. И. И. Грекова. - 2014. - Т. 6. - С. 75-79.

3. Tsimmerman, Ya.S. (2012). Kolorektalnyy rak: sovremennoe sostoyaniye problemy [Colorectal cancer: current state of the problem]. Vestnik khirurgicheskoy gastroenterologii - Bulletin of Surgical Gastroenterology, 2, 50-59 [in Russian].

4. Dumont, F., Goéré, D., Honoré, C., \& Elias, D. (2015). Abdominal surgical emergencies in patients with advanced cancer. $J$. Vasc. Surg., 152 (6), 91-96.

5. Bagnenko, S.F., Belyaev, A.M., \& Zakharenko, A.A. (2014). Neotlozhnaya onkologiya - puti resheniya problemy [Emergency oncology - ways to solve the problem]. Vestnik khirurgii im. I. I. Grekova - Bulletin of Surgery of I.I. Grekov, 6, 75-79 [in Russian].

Електронна адреса для листування: gensur@dsma.dp.ua

\title{
V. P. KRYSHEN, M. V. TROFIMOV, V. V ZADOROZHNYY, A. V. CHUKHRIIENKO
}

Dnipropetrovsk Medical Academy of Health Ministry of Ukraine

Communal Institution "Dnipro Clinical Emergency Care Association" City Council

\section{SUCCESSFUL CASE OF RADICAL SURGERY IN THE LATE STAGES OF COLON CANCER}

\begin{abstract}
The results of treatment of 31 patients with malignant tumors of the colon, complicated by acute intestinal obstruction and colon perforation, peritonitis during 2018 were collected, processed and analyzed in the work. The ratio of surgical interventions was determined depending on the location of the tumor and anatomical features. To illustrate the material, a personal clinical case of radical surgery usage in the colon cancer late stages was presented.
\end{abstract}

Key words: malignant tumors of the colon; radical surgery; intestinal obstruction.

\section{В. П. КРЫШЕНЬ, Н. В. ТРОФИМОВ, В. В. ЗАДОРОЖНЫЙ, А. В. ЧУХРИЕНКО}

Днепропетровская медицинская академия МОЗ Украины

КУ “Днепровская КОСМП" ДГС"

\section{УСПЕШНЫЙ С.УЧАЙ ИСПОЛЬЗОВАНИЯ РАДИКАЛЬНЫХ ОПЕРАЦИЙ НА ПОЗДНИХ СТАДИЯХ РАКА ТОЛСТОЙ КИШКИ}

\footnotetext{
В работе представлены собранные, обработанные и проанализированные результаты лечения 31 больного со злокачественными опухолями толстой кишки на поздних стадиях, осложненными острой кишечной непроходимостью и перфорацией кишки, перитонитом за 2018 год. Было определено соотношение оперативных вмешательств в зависимости от локализации опухоли и анатомических особенностей. Для иллюстрации материала представили личный клинический случай использования радикальных операций на поздних стадиях рака толстой кишки.
}

Ключевые слова: злокачественные опухоли толстой кишки; радикальные операции; кишечная непроходимость. 